\title{
Roman Sources of Canadian Religious History to 1799
}

\section{Luca Codignola}

Volume 50, numéro 1, 1983

Bilan de l'histoire religieuse au Canada

Canadian Catholic History: A survey

URI : https://id.erudit.org/iderudit/1007036ar

DOI : https://doi.org/10.7202/1007036ar

Aller au sommaire du numéro

Éditeur(s)

Les Éditions Historia Ecclesiæ Catholicæ Canadensis Inc.

ISSN

0318-6172 (imprimé)

1927-7067 (numérique)

Découvrir la revue

Citer cet article

Codignola, L. (1983). Roman Sources of Canadian Religious History to 1799.

Sessions d'étude - Société canadienne d'histoire de l'Église catholique, 50(1),

73-88. https://doi.org/10.7202/1007036ar

Tous droits réservés @ Les Éditions Historia Ecclesiæ Catholicæ Canadensis Inc., 1983
Ce document est protégé par la loi sur le droit d'auteur. L'utilisation des services d'Érudit (y compris la reproduction) est assujettie à sa politique d'utilisation que vous pouvez consulter en ligne.

https://apropos.erudit.org/fr/usagers/politique-dutilisation/ 


\title{
Roman Sources of Canadian Religious History to 1799
}

\author{
by Luca Codignola \\ University of Pisa, Italy
}

The importance of the archives and libraries of Rome for the early history of North America is well known. David Beers Quinn, the foremost authority on 16th-century North America, stated that the Roman archives have been far less exploited by historians than the archives of London, Paris, and Seville. According to Quinn, "The major additions to be made will come from Rome, from the Jesuit and Vatican archives [...] The potential additions to our knowledge of the missions and of the whole connection of the Roman Catholic Church [with North America] are very great, and in the end these associations can be documented from such sources on a wholly new level of completeness." ${ }^{1}$ The extensive investigations currently in progress in the archives of the Sacred Congregation "de Propaganda Fide," in the Archivio Segreto Vaticano, and in the Archivum Romanum Societatis Iesu (as we shall see later) have already discovered hundreds of documents, most of them unavailable elsewhere and therefore unknown to historians, that are of great significance for the history of North America as a whole. Moreover, even though most Roman repositories are religious in their origin, the scope of their documentation has a historical significance of which religious history as such is only one of the possible facets. One needs only to think of the well-known Jesuit Relations ${ }^{2}$ to consider the importance for history at large of documents meant to be primarily "religious."

\footnotetext{
${ }^{1}$ David Beers Quinn, "Documenting Canada's Early White History," Archivaria, 7 (1978), p. 90. Quinn wrote from a Canada perspective, but the scope of his article is clearly North American.

${ }^{2}$ Reuben Gold Thwaites, ed., The Jesuit Relations and Allied Documents, Cleveland: the Burrow Brothers, 1896-1901, 73 vols.
} 
The geographical and chronological scope of this survey must be explained. As to geography, since there is no practical distinction in North America between French and British territories until the second half of the 18th century, both are accounted for (that is, what are now Canada and the United States). Conversely, territories that are now within the present borders of the United States but were once under Spanish rule are omitted, since during the colonial period they were treated by the Holy See as the northernmost portion of South and Central America. Louisiana, which for the whole of the period in question presented something of an anomaly, will be included in the survey. The words "American" and "Canadian" are thus used in their broadest meaning. As to chronology, the obvious starting point is 1492, although only random probes have been made in the period prior to 1622 and we cannot be sure of what will eventually be found among Roman documents. The year 1622 is a more logical starting point, since it was at the beginning of that year that Propaganda was established. The terminus ad quem, 1799, was simply chosen because it marks the end of the century and was, besides, a vital turning point for the history of the Holy See. ${ }^{3}$

In Rome there are many archives and many libraries. The distinction between archives and libraries does not always correspond with modern usage. Some libraries preserve many manuscripts, while some archives contain many printed books or pamphlets. The starting point for any historian working in Rome is still Carl Russel Fish's old Guide. Fish worked in Rome from September 1908 until the beginning of August 1909 , to examine "All general references to American or Western Indies and all documents of interest for general American history [...] together with every thing relating to Cuba and the northern provinces and bishoprics of Mexico." "4 Fish did a prodigious amount of research for such a short stay. His Guide is, for modern standards, incomplete and

\footnotetext{
${ }^{3}$ Owen Chadwick, The Popes and the European Revolution, Oxford: Clarendon Press, 1981.

${ }^{4}$ Carl Russell Fish, Guide to the Material for American History in Roman and Other Italian Archives, Washington, DC: The Carnegie Institution, 1911, p. i.
} 
riddled with errors, yet it still stands as the only clue to the importance of Roman repositories in general. ${ }^{5}$

There are currently four projects under way in Rome which systematically try to discover and calendar documents of North American interest in various archival repositories. Of these, two deal with Propaganda, one mainly with the Archivio Segreto Vaticano, and one with the Jesuit archives. The two dealing with Propaganda have recently reached the completion of their first phase, the other two are still under way. In 1955, the Academy of American Franciscan History hired an archivist in Rome, Anton Debevec, to work in Propaganda. The First Series of the Calendar was completed in 1981, and was edited by Finbar Kenneally. While the archivist did his work with great care, the actual editing of the Calendar left much to be desired. Besides, Canadian documents were only calendared when directly connected to the United States in their present borders - a choice that overlooked the fact that, as I have already stated, until the second half of the 18th century those borders were not clearly defined. The First Series refers to the years 1622-1864. The Second Series will cover the years 1865 onwards. $^{6}$

In 1977, the Public Archives of Canada and the Université SaintPaul began a new project, dealing again with Propaganda, which was meant to prepare a calendar of all documents of North American interest relating to the years 1622-1799. Its geographical scope was different from Kenneally's Calendar, in that it took into account the whole of French and British North America. This writer prepared a seven-volume bilingual Calendar that is already available at both sponsoring institutions.

${ }^{5}$ A detailed critique of Fish's Guide as far as Propaganda is concerned was included by this writer in a general survey of all guides, calendars and studies dealing with Propaganda in relationship to North America, 1622-1799. The results of the survey were published in Luca Codignola, "L'Amérique du Nord et la Sacrée Congrégation 'de Propaganda Fide,' 1622-1799. Guide et inventaires," Revue d'histoire de l'Amérique française, XXXIII, 2 (1979), pp. 197-214; Codignola, "L'Amérique du Nord et la Sacrée Congrégation 'de Propaganda Fide,' 1622-1799. Études,' Bulletin du Centre de recherche en civilisation canadienne-française, 21 (1980), pp. 1-12.

${ }^{6}$ Finbar Kenneally, ed., United States Documents in the Propaganda Fide Archives. A Calendar. First Series, Washington, DC: Academy of American Franciscan History, 1976-1981, 7 vols., Index. This writer has reviewed it in Rivista storica italiana, LXXXVII, 3 (1976), pp. 599-605; William and Mary Quarterly, 3rd ser., XXXV, 2 (1978), pp. 419-420. Vol. 8 is the first volume of the Second Series, and is edited by A. Deberec, M.C. Kiemen and A. Wyse. Many of the faults contained in the First Series seem to have been taken in due account by the new editors. 
A preliminary edition in microform has also just been published. All documents calendared will then be made available in microform at the Universite Saint-Paul. ${ }^{7}$ With the two projects outlined above, it may well be said that, up to the year 1799, the inventory of North American material in Propaganda has been completed.

Although "more important than all others taken together," as Fish wrote in $1911,{ }^{8}$ the archives of Propaganda were not the only one in which a search was deemed necessary by Canadian historians. In 1982, the Public Archives of Canada and the Université Saint-Paul of Ottawa started a new project, co-ordinated in Rome by the Canadian Academic Centre in Italy, whose aim was to calendar documents of Canadian interest in Roman repositories other than Propaganda from the beginning to 1799 . This new project, currently under way, is directed by this writer and Pierre Hurtubise (Université Saint-Paul). Monique Benoit and Gabriele Scardellato are the two researchers working in Rome. At the beginning (September, 1982) the real problem was not what to look for, but where to start. The Archivio Segreto Vaticano was selected for its importance, and, amongst its many series, the series Segreteria di Stato, Francia (formerly, Nunziatura di Francia) was deemed to be the most obvious choice, because of the well-known connection between Paris and Canada and the many instances already known (through the Propaganda project) in which the Nuncio in France was known to have had dealings with North America. To date, two portions of the calendar have been completed that cover the years 16501699 (Scardellato) and 1750-1799 (Benoit). ${ }^{9}$ The calendar of the whole series is expected to be completed by 1984 .

Among the archives that were originated by religious orders, the most important by far is the Archivum Romanum Societatis Iesu, if

${ }^{7}$ L. Codignola, Calendar of Documents Relating to French and British North America in the Archives of the Sacred Congregation "de Propaganda Fide" in Rome, 16221799, Ottawa: Public Archives of Canada - Université Saint-Paul, 1980-1983, 7 vols. All general references to Propaganda documents contained in this article are taken from this Calendar. The French transtation was prepared by Ovila Gadouas, OMI.

${ }^{8}$ Fish, Guide, pp. 121-122.

${ }^{9}$ Monique Benoît, Calendar of Documents Relating to French and British North America in the series Segreteria di Stato, Francia of the Archivio Segreto Vaticano, 1750-1799, Ottawa: Public Archives of Canada - Université Saint-Paul, 1983; Gabriele Scardellato, Calendar of Documents Relating to French and British North America in the series Segreteria di Stato, Francia of the Archivio Segreto Vaticano, 1650-1699, Ottawa: Public Archives of Canada - Université Saint-Paul, 1983. 
only on account of the importance of the Society of Jesus in the early history of North America. ARSI is currently being scrutinized by two Canadian scholars, Lucien Campeau (formerly with the Université de Montréal) and Robert Toupin (Laurentian University), the former dealing with the 17th century, the latter with the 18th century. Their approach is indeed different from those of the projects discussed above. Their aim is not to produce a calendar or a topographical inventory of all documents of Canadian interest preserved in ARSI, but to publish in their entirety (at least for the 17th century), documents relating to the history of the Society of Jesus in Canada that are scattered among many repositories around the world, of which ARSI is only one. Judging from the quality of the two volumes that have appeared in print to date, both by Campeau, dealing with the 17 century, one could only hope that the following volumes of the series will soon appear in print, and that the high standard of scholarship set by the first two volumes be indeed maintained. ${ }^{10}$

Amongst Roman archives and libraries, a distinction must be made between the two major repositories (Archivio Segreto Vaticano and Propaganda) and all others. It is a necessary distinction not only on the account of the sheer quantity of documents they preserve, but also because of the kind of material they have. As a rule, documents preserved in ASV and APF tend to be homogeneous as to their origin, as they stem directly from the working apparatus of the Holy See. Most documents relating to the work of the Nuncio in France, for example, are to be found either in ASV (European matters in general) or in APF (missionary matters), since the Nuncio maintained a weekly correspondence both with the Secretary of State and the high officials of Propaganda (the Prefect and the Secretary). Moreover, the ASV is the general repository where most of the Roman congregations (i.e.,

\footnotetext{
${ }^{10}$ Lucien Campeau, éd., Monumenta Novae Franciae, I. La première mission d'Acadie (1601-1616), Rome: Monumenta Hist. Soc. Iesu - Québec: Les Presses de l'Université Laval, 1967; Campeau, éd., Monumenta Novae Franciae, II. Établissement à Québec (1616-1634), Rome: Monumenta Hist. Soc. Iesu - Québec: Les Presses de 1'Université Laval, 1979. It might be worth nothing that all Barthélemy Vimont's and François-Joseph Le Mercier's papers preserved in ARSI have recently been made available in two dissertations: Ferdinando G. Pierotti, I gesuiti in Nuova Francia. Le Lettere del padre Barthélemy Vimont conservate nell'Archivum Romanum Societatis lesu, Università di Pisa (1980); Stefania Pierotti Gigli, I gesuiti in Nuova Francia. Le Lettere del padre François-Joseph Le Mercier conservate nell'Archivum Romanum Societatis Iesu, Università di Pisa (1983).
} 
ministries) have sent their historical archives. It contains, for example, the documents originated by the Sacred Congregation of the Council, the Sacred Congregation of the Rites, the Sacred Congregation of the Consistory, etc. It also contains documents that stemmed from the relationship between the Holy See and the various religious orders (Fondo Gesuiti, Fondo Cappuccini, Fondo Francescani), documents that were once filed by Holy See officials among their private papers (Fondo Albani, Fondo Borghese, Fondo Carpegna), besides documents directly dealing with the missions that, as a rule, should be in APF (Fondo Missioni). ${ }^{11}$

As far as North America is concerned, however, the most important repository is that of Propaganda. Propaganda was established in 1622 to spread the True Faith among the infidels and to protect it where Catholics lived side by side with non-Catholics. This the new congregation was meant to do by co-ordinating all missionary activities and centralizing information on foreign lands. ${ }^{12}$ In this capacity, Propaganda dealt extensively with North America, and only in 1908 were Canada, Newfoundland, and the United States withdrawn from its jurisdiction. ${ }^{13}$ For the whole of the 17th and 18th centuries, Propaganda officials worked according to an almost unchanging pattern that is well reflected by the organization of their archives. Documents received were filed in the series Scritture Originali Riferite nelle Congregazioni Generali when discussed by the Congregation at large, in the series Congressi when discussed by the Prefect and the Secretary alone.

\footnotetext{
${ }^{11}$ Martino Giusti, L'Archivio Segreto Vaticano, Citta del Vaticano, 1975. A preliminary survey of Roman repositories was conducted in 1981 by Francesca Loverci (Università di Roma), in co-operation with this writer. The survey was sponsored by the Istituto Culturale Canadese of Rome. Most information contained in this article dealing with repositories other than Propaganda derives from the Loverci-Codignola republished survey.

${ }^{12}$ Propaganda was officially founded by Gregory XV on June 22, 1622, with the bull Inscrutabili divinae providentiae. The original bull is in the archives of Propaganda [hereafter APF], Miscellanée Diverse, vol. 22, ff. 1rv-4rv. The cardinals of Propaganda, however, met for the first time on March 8, 1622.

${ }^{13}$ On June 29, 1908, with the bull Sapienti consilio, Pius X withdrew Canada, the United States, Newfoundland, England, Scotland, Holland and Luxembourg from the jurisdiction of Propaganda. See Niccolò Del Re, La curia romana. Lineamenti storicogiuridici, Rome : Edizioni di Storia e Letteratura, 1970, pp. 185-203.
} 
Discussions over incoming documents were recorded in the series Acta. Outgoing letters were copied and registered in the series Lettere. ${ }^{14}$

Aside from the Archivio Segreto Vaticano and Propaganda, Rome has a number of archives and libraries that only in comparison with the above two will we define "minor." The documents they preserve, albeit important, are in fact less numerous and less homogeneous as to their origin. The Biblioteca Apostolica Vaticana, the largest among "minor" repositories, contains a number of series that by and large correspond directly to bequests received from various sources - popes, cardinals, Holy See officials in general (Fondo Barberini, Fondo BoncompagniLudovisi, Fondo Borgia, Fondo Chigi, Fondo Ottoboni, Fondo Urbinate, Fondo Vaticano). After Fish, they are known to contain documents relating to Avalon in Newfoundland and New France (Ottoboni), New France (Urbinate), Louisiana (Vaticano), the Capuchins in Acadia (Barberini). ${ }^{15}$ Due to the importance of these collections, the BAV is probably the one among the various "minor" repositories that is likely to contain the most interesting material for the history of North America.

The Biblioteca Casanatense was originally the personal library of cardinal Girolamo Casanate (1620-1700), sometime Secretary of Propaganda (1666-1668). A preliminary survey shows, for example, that the library contains some letters from $\mathbf{M}^{\mathrm{gr}}$ Agostino Favoriti, a high official of the Roman courts, to François de Laval, the first bishop of Québec, dated 1671-1675 (ms 367), and a printed dossier on the Seven Years War with specific reference to North America (ms 5556). ${ }^{16}$

\footnotetext{
${ }^{14}$ There are, of course, many minor series. See Josef Metzler - Nikolaus Kowalski, Inventory of the Historical Archives of the Sacred Congregation for the Evangelization of Peoples or "de Propaganda Fide," Rome: Pontificia Universitas Urbaniana, 1983. For a general appraisal of its archives in relationship with North America, see Codignola, "L'America del North nei documenti dell'Archivio della Sacra Congregazione 'de Propaganda Fide,' 1622-1799. Una introduzione," in Codignola, ed., Canadiana. Storia e storiografia canadese, Venice: Marsilio Editori, 1979, pp. 33-45. See also Codignola, Calendar.

${ }^{15}$ Jeanne Bignami, Odier, La Bibliothèque Vaticane de Sixte IV à Pie XI. Recherches sur l'histoire des collections de manuscrits. Città del Vaticano: Biblioteca Apostolica Vaticana, 1973; Bignami Odier, "Guide au Département des manuscripts de la Bibliothèque du Vatican," Mélanges d'archéologie et d'histoire, 51 (1934), pp. 205-239.

${ }^{16}$ G.D. Anagni - C. de Ferrari, Index Manuscriptorum, 1844, 3 vols.; A. Moricca Caputi, Inventario (topografico) manoscritti, 1915, 2 vols.; E. Moneti et al., Catalogo dei manoscritti della Biblioteca Casanatense, 1949-1978, Rome: Libreria déllo Stato, 6 vols.
} 
The Biblioteca Vallicelliana, established in the second half of the 16th century by St. Filippo Neri, is considered of particular relevance for ecclesiastical history. The library seems to be very rich in general reports on world affairs, particularly on France and England. A number of documents seem to be likely to contain information on North America (mss G 47, K 13, K 102, K 104, M 13-14, R 55, S 38-45). ${ }^{17}$

The Biblioteca dell'Accademia Nazionale dei Lincei e Corsiniana was initially the private library of the Corsini family and in particular of Lorenzo Corsini, then Pope Clement XII (1730-1740). In 1883 it was donated to the Accademia Nazionale dei Lincei that merged its own library with the former Biblioteca Corsiniana. The Biblioteca is known to contain a dossier of the Holy Office dealing with the state of the Catholic church in Canada after the Conquest (ms 2555/1), a good number of documents dealing with the French Nunciature in the 17th and 18th centuries, a dossier on Propaganda missionaries in England (ms 244), and documents on the French Recollets in the 18th century (mss 713,912 ), about whom little is available elsewere. ${ }^{18}$

The Archivio di Stato di Roma is the general repository for the Papal States prior to their merging with Italy in 1870. Even though it is Italian in scope, it contains many documents of interest for the history of the missions and their administrative problems. A document, for example, was found that deals with the Sulpician Seminary of Montreal (Archivio Paesi Stranieri, secc. XVII-XVIII, b. 28, Inghilterra, anni 1510-1830). ${ }^{19}$

The Biblioteca Nazionale Vittorio Emanuele II is the national library of Italy. It was established by incorporating the series preserved in the suppressed Roman congregations at the time of the Italian unification. Of the five series into which the manuscript division is divided, only one does not seem to have any material pertaining to North America

\footnotetext{
${ }^{17}$ Index codicum manuscriptorum, 2 vols.; Index codicum manuscriptorum, Appendix, 1887-1889, 3 vols.; Index materiarum praecipuarum codicum manuscriptorum graecorum et latinorum Bibliothecae Vallicellianae ordine alphabetico depositus, 1749; I manoscritti di Costantino Corvisieri nella Biblioteca della R. Societa di Storia Patria, 1908.

${ }^{18} \mathrm{~A}$. Arrigoni et al., Indice generale dei libri manoscritti che si conservano nella Libreria dell'Ecc. ma Casa Crosini, 1738-1958, 3 vols.; Inventorio dei manoscritti corsiniani, 2 vols.

${ }^{19}$ Armando Lodolini, L'Archivio di Stato di Roma. Epitome di una guida degli archivi dell'amministrazione centrale delle Stato Pontificio, Rome: Istituto di Studi Romani Editore, 1960.
} 
(Fondo Orientale). The four of interest are Fondo Vittorio Emanuele, Fondo Gesuiti, Fondo Sessoriano, Fondi Minori. The Fondo Gesuiti has many documents relating to the missions of the Society, while the Fondo Sessoriano has a dossier on the Quebec church at the beginning of the 18th century (ms 230). ${ }^{20}$

Most religious orders keep their general archives in Rome. Their archives must be approached selectively, according to the time periods in which the orders were active in certain areas of North America. The Archivio Generale dell'Ordine dei Carmelitani Scalzi, for example, contains documents relating to the early history of Newfoundland, 21 and is likely to contain material on their endeavours in Louisiana at the beginning of the 18th century. The Archivio Generale dei Frati Minori Cappuccini, thougn never surveyed, is likely to preserve documents relating to Acadia in the first half of the 17th century, where the Capuchins operated extensively. The Spiritans were active in 18th-century Nova Scotia and in Saint-Pierre and Miquelon, and that is the period one must look for in their Archivio Generale dei Padri dello Spirito Santo. The Jesuit archives in Rome were already dealt with above.

Prior to 1622 (that is, prior to the establishment of Propaganda), the documents one is likely to find in Roman archives are occasional as to their origin. The Cantino map of $\mathbf{1 5 0 2}$ was found by sheer chance in a pork butcher's shop in Modena. ${ }^{22}$ Girolamo da Verrazzano's 1529 map of the East Coast of North America was found in the Biblioteca Apostolica Vaticana. In Bologna (once, with Modena, part of the Papal States), there is one of the three extant copies of Samuel de Champlain's Brief Discovrs of 1601, the second copy being in Turin and the third (the more famous one) in the John Carter Brown library of Providence,

\footnotetext{
${ }^{20}$ Tullio Tentori, "I manoscritti di interesse americanistico esistenti nelle Biblioteche ed archivi italiani. I manoscritti della Biblioteca Nazionale Centrale di Roma," Accademia Nazionale dei Lincei, Rendiconti della Classe di Scienze Morali, Storiche e Filologiche, ser. VIII, vol. VIII, 5-6 (1953), 263-277.

${ }^{21}$ Codignola, Terre d'America e burocrazia romana. Simon Stock, Propaganda Fide e la colonia di Lord Baltimore a Terranova, 1621-1649, Venice: Marsilio Editori, 1982.

${ }^{22}$ William P. Cumming - Raleigh, A. Skelton - David B. Quinn, The Discovery of America, London: Elek, 1971, p. 56.
} 
RI. ${ }^{23}$ Among the many hundreds of items, Fish lists a document relating to a 1611 voyage to China by way of Nova Zembla where New France is mentioned, possibly a clue to one of Henry Hudson's voyages of discovery. ${ }^{24}$ Very interesting documents all of them, and yet occasional in nature, the result more of happy encounters with the unexpected rather than of planned research.

After 1622, this pattern continues to apply to most of the Roman repositories, with the notable exceptions of the Archivio Segreto Vaticano, of Propaganda and of the archives of the religious orders. Pope Urban VIII liked a map of North America so much that he took it from Propaganda, to which it had been sent, and never gave it back. ${ }^{25}$ It was the rule among Holy See high officials to take home the papers they were working at; often they disappeared, to surface after their death in private libraries or collections. ${ }^{26}$ Favoriti's letters to Laval, now in the Biblioteca Casanatense, are probably there because Favoriti was one of Casanate's colleagues in the Roman curia. It is often possible to retrace the reason for the disappearance of the document from where it should belong and its surfacing somewhere else. It is almost impossible, however, to outline general rules or establish working patterns.

This seems to be less the case with the archives of the religious orders. As I have already stated above, one needs to know the time periods in which a certain order was active in North America, and is then likely to find evidence of their endeavours. In some instances, however, schemes were discussed that never materialized. The following story is worth noting, since it well shows the random whereabouts of documents and their complementarity. In the 1620's the Discalced Carmelite Simon Stock was planning to establish a Catholic colony in Newfoundland, in the Avalon peninsula that belonged to George Calvert, Lord Baltimore. Stock's English confreres were against the project, and Stock had applied to Propaganda for help. Before reaching

\footnotetext{
${ }^{23}$ [Samuel de Champlain], Brief Discovrs [... ] aux Indes Occidentales, [1601], in Henry Percival Biggar, ed., The Works of Samuel de Champlain, Toronto: The Champlain Society, vol. 1, 1922, pp. 1-80. The printed version is taken from the Providence copy. Whether the Brief Discovrs was authored by Champlain himself is still being debated.

${ }^{24}$ Fish, Guide, p. 115.

25 [Propaganda] to Simon Stock, Rome, Dec. 2, 1628, APF, Lettere, vol. 7, f. 163r. See Codignola, Terre d'America, p. $88 n 35$.

${ }^{26}$ Chadwick, Popes and European Revolution, p. 299.
} 
a final decision, however, the superiors of the order in Rome had commissioned a report on the whole scheme to Bede of the Blessed Sacrament, one of Stock's confreres in England. Bede replied with a "brief $[\ldots]$ relation on the English plantation in Virginia and other parts thereabouts" which, while showing that the author knew nothing at all about the existence of Avalon, contained interesting details about North America in general. After Virginia, "a province contiguous with the land of Florida on the eastern shore," the English had colonized Bermuda, "it having happened that a ship was wrecked there." Later, when other discoveries had been made towards "the country which is called the land of Labrador," the English had founded New England, first called "Norumbega," then New France by the French, then "New England and New Scotland" by the English, while the natives went on calling it "Canada." There followed an account of the motives which had induced the English to go to the New World. Bede's report did not remain as an internal document regarding only the order of the Discalced Carmelites. The higher ranks of the order, in fact, decided to use it in order to place Stock and his project in an unfavourable light in the eyes of Propaganda. Moreover, since they wanted to keep the information contained in the report for themselves, they resolved to send to Propaganda not the original report, but an abstract of it, from which they had eliminated all place-names (Virginia, Florida, Bermuda, Labrador, Norumbega, New France, New England, New Scotland, Canada) and their geographical co-ordinates, leaving only the reasons which had induced the English to seek fortune in the New World, and, of course, all the unfavourable comments on the Avalon entreprise. By doing so, they rendered the report incomprehensible and also eliminated any interest it might arouse or any appearance of novelty it might have had. ${ }^{27}$

Of the Archivio Segreto Vaticano we do not know enough yet to outline a general pattern. A proper investigation has in fact just begun, and Fish's Guide is still useful to some extent, especially to prove the magnitude of its holdings. On account of the fact that, since 1622, every Catholic in North America was spiritually dependent on

\footnotetext{
${ }^{27}$ The whole story is discussed in Codignola, Terre d'America, pp. 48-51. The original report is Bede of the Blessed Sacrament to Paolo Simone di Gesùe Maria, London, Oct. 24, 1625, Archivio Generale dell'ordine dei Carmelitani Scalzi, Missiones Europa Anglia. P. Beda a SS. Sacr.: Litterae \& relationes 1625/27, ms 271.h, ff. 3rv4rv. The doctored version is [Bede] to [Paolo Simone], [London Oct. 24, 1625], APF, SOCG, vol. 189, ff. 347rv-348rv.
} 
Propaganda, the relationship between North America and the Holy See in the 17th and 18th centuries is nowhere better documented than in the archives of Propaganda. Since the archives of Propaganda are also better known than other Roman repositories, it is possible to be more specific about the general pattern of this two-way relationship. The two questions I will now discuss are, first, who were the people that corresponded with Propaganda in relationship to North America. Secondly, how did Propaganda react to their letters. ${ }^{28}$

The Nuncio was the highest Holy See representative in France. Although unlikely to be particularly interested in North American events, the Nuncio was usually well informed on activities in the Court, thus helping Propaganda to understand the essential background to the American colonies of the Most Christian King. As a trained diplomat, he knew better than anybody else how to deal with Propaganda officials. He wrote on a weekly basis, always acknowledged letters received, duly answered queries, clearly stated new items on which decisions had to be taken. His letters were short and clear. Propaganda officials found them easy to process, and answered in similar style.

The bishops of Quebec and Baltimore usually wrote once a year and combined a general report on the state of religion in their dioceses with a list of requests. François de Laval was particularly keen in keeping up his correspondence with Propaganda. Jean-Olivier Briand appointed a vicar general in Paris, who acted as his liaison with Rome and Propaganda. The four successive vicars general in Paris (Pierre de La Rue, better known as abbé de l'Îsle-Dieu, 1734-1777; JosephMarie de La Corne de Chaptes, 1762-1779; François Sorbier de Villars, 1777-1788; Martin Hody, 1789-1792) forwarded and often filtered to Rome an enormous amount of correspondence coming from North America. When the French Revolution disrupted the customary network, the correspondence between Canada and Rome went via Lisbon, where the Québec merchant Francis Morrogh acted as a practical contact. Since after the Conquest Canada was an English possession, a number of matters were dealt with in London, not in Paris, where Thomas Hussey was appointed vicar general of the bishop of Quebec. Like his

\footnotetext{
${ }^{28}$ For a general interpretation of the Holy See's American policies, see Codignola, "Rome as Atlantic Power, 1622-1799. The Interpretive Framework," Annali del Comitato Italiano per la Storia Nordamericana, 1 (1983), forthcoming.
} 
French colleagues, Hussey too had a long correspondence with Propaganda. ${ }^{29}$ As to the British continental colonies, the vicar apostolic in the London district, Richard Challoner, bishop of Debra, enjoyed token jurisdiction over the few Jesuit missionaries who were active there. After the War of American Independence, John Carroll was first appointed prefect apostolic of the missions in the United Provinces of America (1784), and then bishop of Baltimore (1789). Like his colleague in Quebec, Carroll corresponded directly with Propaganda, but often used Hussey in London to keep up with correspondence with Rome. ${ }^{30}$

The letters of individual missionaries were, however, the ones that plunged the bureaucrats of Propaganda deeper into the reality of the New World. Since there was no routine correspondence with them, these letters were special. Often they contained requests for faculties and privileges, sometimes for help against hostile superiors. In some cases, no request was made. In 1668, Pierre de Neufville, a secular priest from the diocese of Coutances, wrote to Propaganda reporting on the abuses of French, Spanish, Basque and Italian fishermen. To make the most of their stay, these men even worked on Sunday arranging their catch while Indians and pirates preyed upon them along the shores of Newfoundland. Neufville was not aware that in order to perform his duties he needed special faculties that could only be granted by Propaganda, since he had been going to Newfoundland every summer for the previous four years with the consent of his French ordinary, the bishop of Saint-Malo, François de Ville-Montée. ${ }^{31}$ Around 1765, a report on Louisiana written by the Jesuit François-Philibert Watrin found its way to the desks of Propaganda. Officials were informed that the Illinois,

\footnotetext{
${ }^{29}$ Ivahoë Caron, "Les évêques du Québec, leurs Procureurs et leurs vicaires généraux à Rome, à Paris et à Londres (1734-1834)," Mémoires de la Société Royale du Canada, 3ème sér., 29 (1935), sec. I, pp. 153-178. On Francis Morrogh, see Jean-François Hubert to Leonardo Antonelli, Québec, Nov. 7, 1791, APF, SOCG, vol. 894, ff. 132rv-139rv.

${ }^{30}$ James Hennesey, American Catholics. A History of the Roman Catholic Community in the United States, New York: Oxford University Press, 1981, pp. 69-88. On the years 1754-1784, Codignola, "L'America del Nord nei documenti dell'archivio della Sacra Congregazione 'de Propaganda Fide' (1754-1784)," in Giorgio Spini et al., Italia e America dal Settecento all'eta dell 'imperialismo, Venice: Marsilio Editori, 1976, pp. 127147.

${ }^{31}$ Pierre de Neufville to Clement IX, [Rome], [1668-9], APF, SOCG, vol. 418, ff. 234rv-235rv; Neufville to Propaganda, [Rome], [1669], id., vol. 419, f. 390rv; Proceedings of the General Congregation of March 26, 1669, item no. 25. id., Acta, vol. 38, pp. 55-56; Proceedings of the General Congregation of May 13, 1669, item no. 43 , id., pp. $212-213$.
} 
who sixty years before numbered 10,000 , were now reduced to 800 or 900 , and that the cause of their decline rested with "la frequentation des François." Watrin explained: "Ils veulent jouir des douceurs dont ils voient l'usage parmi les François; ils s'amolissent, et ne peuvent plus resister à la vie dire qu'il faut mener malgré soi quand on passe comme eux l'hiver au milieu des bois." ${ }^{32}$ In 1785, the Capuchin Charles Maurice Whelan, recently arrived in New York, wrote to the Nuncio in Paris, Giuseppe Doria Pamphili, to report on his adventurous career. He had been chaplain in the French fleet commanded by FrançoisJoseph-Paul, Comte de Grasse, who was defeated at Les Saintes on April 22, 1782. A prisoner in Jamaica for thirteen months, he ministered to 3,562 Frenchmen, 800 Spanish and 35 Americans, before finding his way to the United Provinces of America. Adding a cosmopolitan touch to his report, he ended his letter by suggesting that any priest operating in New York at least had to speak Irish, English, French and Dutch, and that some Spanish and Portuguese were also advisable. Whelan's letter was subsequently forwarded by the Nuncio to Propaganda. ${ }^{33}$ Every example is a case-study in itself, and the list is virtually endless. Significantly, each item eventually ended up in the hands of the same people in the offices of Propaganda.

All incoming correspondence was quickly and efficiently processed according to a ritual working style that went almost unchanged for two centuries. The historian is somewhat frustrated when, searching in the archives of Propaganda for universal views of European colonization of the New World, general considerations on the conversion of native populations, overall plans for re-converting North American heretics to Catholicism, he finds next to nothing. But Propaganda officials were administrators, not intellectuals, and were too busy with pending business to devote any significant portion of their precious time to discuss the overall meaning of their task. (After all, their Faith was there to provide all the answers.) They did not have much time to read, either. They most appreciated letters whose requests were clearly singled out and in which general descriptions kept to a minimum. The nuncios, as we have seen, were masters in the art of letter-writing. Conversely, individual

\footnotetext{
${ }^{32}$ François-Philibert Watrin to |Pietro Pamphili Colonna |, |France, 1765|, APF, Congressi, America Centrale, vol. 1, f. 428v.

${ }^{33}$ Charles Maurice Whelan to |Giuseppe Doria Pamphili|, | New York|, Jan. 28, 1785 , id., vol. 2 , ff. $442 \mathrm{rv}-443 \mathrm{rv}$.
} 
missionaries were often verbose, and sometimes did not even have any special requests. In this case, the letter was not processed, and it was likely to disappear in the archives. This is what happened to the first general description of North America to reach Propaganda, a report written in 1625 by the Recollet Gregorio de Bolívar, which was never discussed, let alone used. ${ }^{34}$

To be sure, North America was not a priority in the cardinals' agenda. When they first met, on March 8,1622, to divide the various parts of the world among themselves, only Brazil and the West Indies were mentioned. ${ }^{35}$ Both North and South America were regarded as places of far lesser importance than, for example, Germany, Illyria, Albania, the East Indies or the Slav countries. ${ }^{36}$ Later, when Pope Pius VI sent the Nuncio Diria Pamphili to attend to the preliminaries of the Treaty of Paris that would have settled the War of American Independence, he had it made clear that, after all, the future treaty was not very important, although some thoughts must be given to the status of the Catholics in the new republic. ${ }^{37}$ And yet the sheer quantity of North American material dealt with by Propaganda from the 1760's onwards shows that a new awareness had replaced the geographical confusion that North America had caused to the early officials of Propaganda. It is worth nothing, for example, that out of 460 letters of North American interest written by Propaganda in the years 1622-1799 (177 years), 154 (33.5 percent) were written between 1622 and 1759 (137 years, or 77.4 percent), while 306 ( 66.5 percent) between 1760 and 1799 ( 39 years, or 22 percent).

\footnotetext{
${ }^{34}$ Relaçion de la Virginia por fr. Gregorio de Bolivar menor observante Predicator de la Yndia Ocidental, [Rome, 1625], APF, Miscellanée Varié, vol. 6, f. 194rv. On Bolivar's report, see Metzler, "Der alteste Bericht über Nordamerika un PropagandaArchiv," Neue Zeitschrift für Missionswissenschaft, XXV (1969), pp. 29-37; Codignola, Terre d'America, pp. 39, 102-103.

${ }^{35}$ Proceedings of the General Congregation of March 8, 1622, APF, Acta, vol. 3, ff. 3rv-5rv.

${ }^{36}$ The series SOCG, which contained all "important" incoming documents, has (for the period 1622-1668) only two volumes relating to North America out of a total of 417, against, for example, 39 for Germany, 34 for Illyria, 29 each for Albania, the East Indies and France, 27 for Poland, 25 for Switzerland, and so on. In the years 1622-1668 (vols. 1-417) SOCG documents were arranged by geographical areas; from 1669 onwards (vols 418 on) documents were arranged chronologically.

${ }^{37}$ [Propaganda] to Doria Pamphili, [Rome], Jan. 15. 1783, APF, Lettere, vol. 242, f. 60rv.
} 
Even though much work has been done in the past ten years, a lot remains to be done. In view of the quantity of documents preserved in Roman archives, the real problem facing researchers and sponsoring institutions is one of priorities. Since the Propaganda project up to the year 1799 is new completed, my suggestion is that future projects take into account first, what we have defined as "minor" Roman archives, whose riches have as yet never been properly investigated, and secondly (or concurrently) the 19th-century documents preserved in Propaganda, whose importance we know from secondary sources already in print, but that have never been systematically calendared.

\section{Biographical Note}

Luca Codignola, born in Genoa, Italy, in 1947, is Associate Professor of Early North American History at the Universita di Pisa. He is the author of Guerra e guerriglia nell'America coloniale 1754-1760 (1977) and Terre d'America e burocrazia romana 1621-1649 (1982). He has also edited Francis Parkman: Scritti scelti (1976), Canadiana. Aspetti della storia e della letteratura canadese (1978), Canadiana. Storio e storiografia canadese (1979), and Canadiana. Problemi di storia canadese (1983). 